\title{
Spindle Cell Melanoma
}

National Cancer Institute

\section{Source}

National Cancer Institute. Spindle Cell Melanoma. NCI Thesaurus. Code C4237.

A melanoma characterized by the presence of malignant spindle-shaped melanocytes. 